\title{
Political Ideology To Reduce Conflicts Of Interest In The Wetlands Of Thale Noi, Phatthalung Province, Thailand
}

Surachet Chiramanee, Prince of Songkla University, Thailand Chidchanok Churngchow, Prince of Songkla University, Thailand Rotchanatch Darnsawasdi, Prince of Songkla University, Thailand

\begin{abstract}
This article studies measures to ease conflicts between locals and government officials regarding consumption of natural resources in the Thale Noi wetlands. The problems incurred by the wetlands are a function of their physical properties, location, and the significance of their natural resources. Previously, the extent of these problems was measured by the failure of efforts to solve them. The new methodology proposed for solving problems is based on political philosophy. This study proposes the elimination of confrontations and legal punishment in favor of participatory, democratic, trustful, and reciprocal agreement among the conflicting parties. The conflict area is zoned based on the severity of each problem, the nature of the associated conflicts, and the potential of law enforcement to solve them. A participatory committee is formed to alleviate conflict and confrontation between locals and government officials. These measures can be applied to other conflict areas in Thailand.
\end{abstract}

Keywords: Conflict Management; Law Enforcement; Participatory; Political Ideology; Thailand

\section{INTRODUCTION}

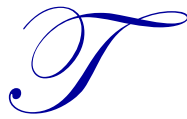

his study refers to political principles in developing measures to solve natural resource usage conflicts among people from different occupational groups and between different groups and officials in Thale Noi. The wetlands of Thale Noi are located in the northernmost part of Songkhla Lake, the largest lake in Thailand. The Thale Noi wetlands cover an area of 114,250 acres in the three provinces of Songkhla, Nakhon Si Thammarat, and Pattalung. Its natural value lies in the richness and variety of its wild plants and marine animals. It is a fertile area of bog forests with spikerush and contains plentiful food for birds and marine animals. The Pru Kuan Kee Sian area in Thale Noi has been promoted as Thailand's first Ramsar Site since 1998. A population of 37,951 - or 6,326 households (Songkhla Rajabhat University, 2009) - inhabits the wetlands.

The importance of the Thale Noi wetlands is as follows:

1. Thale Noi is rich in fishery resources, with a wide variety of freshwater species like walking catfish, barb, and snakehead mullet. Dried fish, pickled fish, and pickled fish stomach are delicacies of the southern provinces and are well-known fish products throughout Thailand. The preserved fish products are famous homemade goods of Thale Noi.

2. The Irrawaddy dolphin, fishing cat, Malayan horseshoe bat, long-tailed macaque, and blue-spotted pipefish are rare aquatic animals found in Thale Noi.

3. Several types of plants are listed by the Convention on International Trade in Endangered Species (CITES), such as three types of orchids - spider, Cymbidium finlaysonianum, and Cymbidium aloifolium. There are many aquatic plants, such as Hanguana malayana, seashore screwpine, and several types of lotuses. These lotuses are one of Thale Noi's tourist attractions. Spikerush is also abundant in Thale Noi, which is used for basketry - a major source of income. 
4. Thale Noi is a lake with several land mounds that are ideal nesting grounds for a huge number of local and migrating birds. Pru Kuan Kee Sian (bog forest) is well known as a tourist attraction and is an ideal site for research in wetland studies.

5. Thale Noi is a huge and very important source of fresh water for household and agricultural use. It is also an important waterway for transportation in the area and is used for storing fresh water in case of scarcity and, at times, for the prevention of floods in the rainy season.

6. Thale Noi is a huge wetland overlying plant ruins and animal remains, which makes it a very fertile area for all types of trees and plants. Among these are cajeput trees, which are widely used in building and making charcoal. The Thale Noi wetlands are also invaluable as areas absorbent of poisonous and toxic substances and as a blockade preventing seawater from flooding the land.

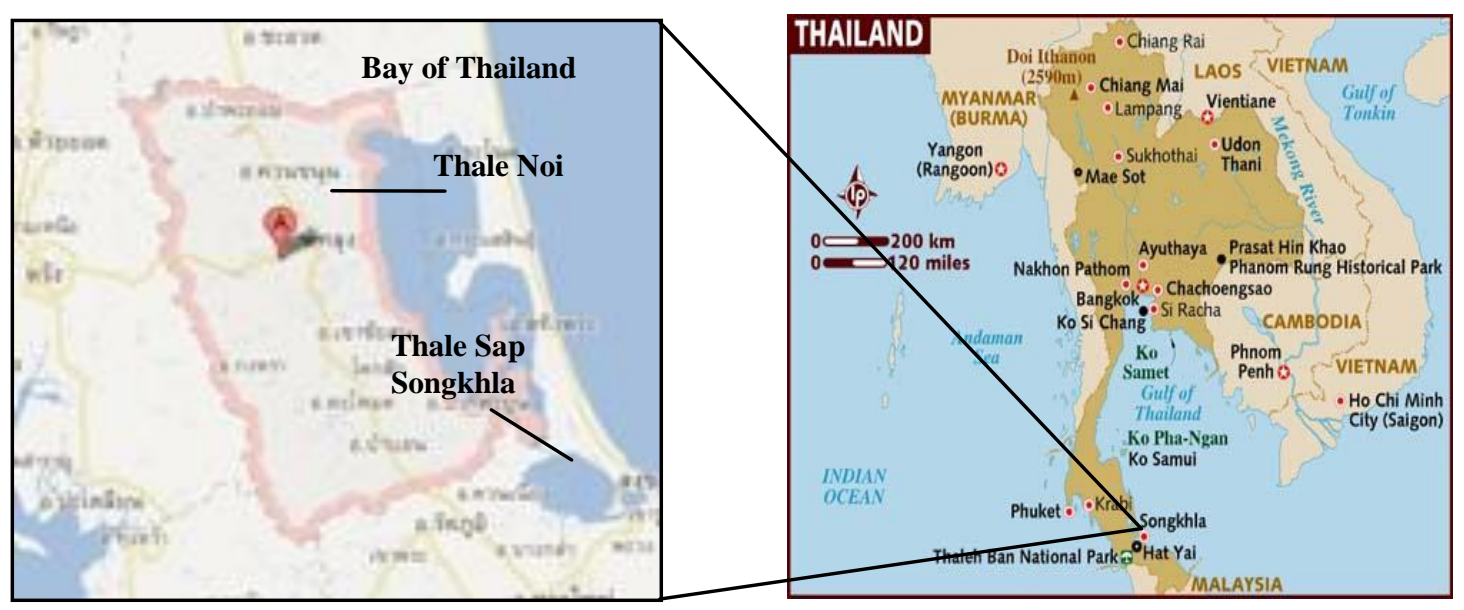

Figure 1: Map of Thale Noi

Source: Geographic Information System (GIS) Center of Prince of Songkla University Hatyai, Songkhla Thailand

\section{PROBLEMS AND THREATS FACING THALE NOI}

The wetlands of Thale Noi have been invaluable for the livelihood of a large number of people living around the area. The area is now confronting serious problems and threats, which are described in the following section.

\section{Threats To Fishery Resources And The Extinction Of Species}

Rutaiwan (1993) found that decreased fishery resources in Thale Noi were a cause of poverty in the surrounding areas. Deteriorating water quality caused by household wastewater and spikerush dye diminish the quantity of fish in Thale Noi. Also, Maneepong (1998) reported the contamination of water with heavy metals. Kaewrak (2007) conducted a study in three parts: 1) before establishment of the Thale Noi non-hunting area in 1975,2 ) covering the period 1975-2004, and 3) in 2005. The results revealed that the number of fish was decreasing rapidly. The National Institute of Coastal Aquaculture (2010) showed that the number of aquaculture species in the Thale Noi area has decreased, some to the point of extinction. At present, there is an aquaculture area for walking catfish because their numbers have decreased dramatically. Also, a large number of fish are food for many local and migrating birds. Migrant birds that visit during the months of December through March have reduced the number of fish in the Thale Noi wetlands.

\section{The Threat Of The Decreasing Number Of Natural Plant Species}

The number of local plant species in Thale Noi has been decreasing gradually over a 10-year period. Liengponpan (1998) showed that 72 plant species were found in 1998, 54 in 2000, 38 in 2005, and only 25 in 2009. The extinction of these local plant species signified the threat to the fertility and diversity of the local fauna, which is the real threat to the whole ecology in Thales Noi. 


\section{Problems And Decline In The Number Of Bird Species}

Angkaprechasete (1985) found 149 species of local and migrant birds in the area of Thale Noi between 1978 and 80. Twenty years later (in 2000), there were 140 species of birds in the area (Liengponpan, 1998). Ten years later, the Research Center of Marine and Coastal Resources surveyed 101 species of birds. The threat to birds in this area was due to buffalo rearing, wild fires in bog forests, and some tourism activities such as long-tailed boat trips, bird watching, and trekking.

\section{Problems Of Water Contamination}

Na Chiengmai (2009) examined the water in the area of the open sea called Thale Luang and the area outside the Thale Noi freshwater lake and found contamination by heavy metals; namely, zinc and cadmium. Later, Maneepong and Rak-keaw (1999) found a larger quantity of brass, zinc, nickel, cadmium, and chromium in Thale Noi than in Thale Luang. The results showed a low quality of water in some parts of the lake and at certain periods of time that are attributable to agricultural activities in the nearby areas. Kantacha (1999) found that the contamination of lead and chromium in Thale Noi resulted from wastewater from the spikerush dyeing process. Chromium was not found to exceed the acceptable safety levels, though lead was found to exceed the safety criteria by 1.6 (Kantacha, 1999). Sipodjanart (2005) performed a study of household waste in the Thale Noi area. He found that littering the ground under houses was common behavior among the local people and that they had a lower sense of civic consciousness. dyeing:

The Department of Pollution Control also reported excess quantities of four heavy metals from spikerush

1. Brass was found in amounts triple the safety limit. Excessive exposure to brass causes the "fever of brass cough", destroys taste sensitivity, and causes anemia.

2. Lead was found in amounts double the safety limit. Excessive exposure to lead causes illnesses with symptoms such as nausea, vomiting, and cramps. Human kidneys can be destroyed and victims can die a couple days after exposure. Lead also causes some other chronic conditions such as headaches, pale skin, anemia, emaciated muscles, and paralysis.

3. Zinc was found to exceed the safety limit. Overexposure to zinc causes conditions with symptoms such as headaches, high fever, and shivering. In severe cases, the patient suffers flooded lungs, which can be fatal. Long-term zinc contamination can cause cancer.

4. Cadmium can cause Itai-Itai disease, which shows in the erosion of bones, damage to kidneys, and pain in bones and joints.

\section{Problems In The Deterioration Of The Bog Forest}

The deterioration of the bog forest area resulted from human mishandling and natural phenomena as described as follows:

1. There were two important sources of fires in the bog forest. First, fires were set on purpose so that the area could be used for residential purposes and to cultivate oil palm and rubber. The second was wildfires, which normally occur in the hot season when the water level in the bog forest is low and the forest floor is full of dry leaves and tree ruins that catch fire easily. These wildfires usually destroy a wide area of the bog forest. Finally, narrow canals, known as "chicken's small intestine canals", which are meant to carry water from the bog forest to agricultural areas, further reduced the level of water in the bog forest so that dry areas caught fire easily.

2. Invasion of the bog forest for agricultural purposes also resulted in people clearing the area. Formerly, no restrictions were made for the conservation of the bog forest area; recent declaration of restricted and conservation areas impinged on areas that many local people had used for either agricultural or housing purposes. The existence of these overlapping areas has resulted in prolonged conflicts between the local people and authorities in the Thale Noi wetlands. 
3. The laws passed to protect the area are ineffective. There are three laws concerning these conflicts: 1) the Wildlife Preservation and Protection Act of B.E. 2535 (1992), 2) the National Reservation Act B.E. 2507 (1964), and 3) the Forest Act B.E. 2548 (2005). According to the laws, landowners have the right to do anything with their own land, such as clear it for oil palm plantations and use pesticides, chemical fertilizers, and weed-killing chemicals. These chemical substances contaminated the surrounding areas, including the bog forest areas.

\section{Problems Of Law Enforcement}

The Thale Noi Non-Hunting Area Office, Department of Fishery, Department of Forestry, Department of National Parks, Wildlife and Plant Conservation of the Ministry of National Resources and Environment, Thale Noi Tamboln Municipality, and Panangtung Tamboln Municipality have worked on tackling these problems through strict enforcement of the laws by arresting those who illegally use electric circuits or chemicals for fishing, build their houses in the non-hunting areas, and invade and clear non-hunting areas for agricultural purposes. The responsible officers from the Department of Fishery and Non-Hunting Units have taken the responsibility of arresting offenders and bringing the cases to court.

In cases of land invasion, people who lived in the area without legal documents have been arrested and brought to court. Since there are only 61 officers for 114,250 acres, enforcing the law to help save Thale Noi resources is a very difficult job. As a result, the landowners who have the documents for notification of land have still had difficulties proving their legal possession. Currently, 1,460 acres of land are in conflict and it will take over 10 years to prove legal possession.

Problems in enforcing the law include:

1. The Thale Noi Tambon Municipality and Panangtung Tambon Municipality, which are responsible for controlling and managing the areas, have not issued subdivision laws; thus, no measures to deal with those who damage the environment have been formulated. The law requires residents to install fat-capturing gadgets to treat their household wastewater before releasing it into the natural water resources.

2. The responsible officials have not taken any action against those who violated the laws, perhaps because those officials did not want to lose popularity when they stood for elections.

\section{RESULTS}

\section{Solutions For Past Environmental Problems}

Boonprakarn (1999) found that there were conflicts of interest among the people in the area, which, in turn, created conflict between the officials and different groups of inhabitants in the area surrounding Thale Noi. Kaewrak (2007) conducted a study on problems and conflicts in the area and reported three types of conflicts:

1. There were conflicts among the local people for the natural resources of Thale Noi. These revolved around spikerush products, fish netting, boat routes, and boat trips for bird tours. Some people also complained about the large number of birds that moved to the area, damaging natural spikerush areas.

2. There were conflicts between people in the area and government officials. Some examples involved the invasion of land and land clearance for fishing or agricultural purposes, mostly for rubber and oil palm plantations. When legal action was taken against these violations, the people concerned conveyed their grievances to higher levels of administration, complaining that they were not treated fairly by the officials. Some even brought the cases to court, and it took a very long time before the cases could be resolved.

3. There were conflicts between government sectors; one involving a building constructed by the local administration in a restricted area. This case was brought to court by the officials in the non-hunting area.

Due to severe conflicts, some areas were set on fire by local people to attract the attention of higher levels of administration. From October 2009 to October 2010, there were 295 fires and an area equivalent to 7,221 acres was burned down. The fires in October 2010 were the most damaging. The natural environment of the area was 
destroyed. The Minister of Natural Resources and Environment at that time surveyed the area and its problems and took the case as an urgent one.

\section{Application Of Political Philosophy To Solve The Conflicts}

The application seeks to redress the conflict between local people and government officials through mutual social agreements that establish some rules and frameworks. The parties were to agree to use natural resources fairly to reduce conflict (adapted from Bill \& Hardgrave, 1973). All stakeholders and government officials were brought together to solve the problems of natural resources in the Thale Noi area.The researcher proposed four procedures based on political principles to obtain mutual agreements from all involved people. These procedures include 1) participatory democracy, 2) trust, 3) disciplining without punishment, and 4) formation of a recognized committee for solving the conflicts.

\section{Participatory Democracy}

Democracy is a political system that allows people rights and freedoms in making decisions that can influence the country's direction; it has been adopted in most countries. People choose representatives to make decisions. In participatory democracy, the people retain some rights (Lindsay, 1992) which include the initiation of laws, the impeachment of politicians, and public hearings. This is also known as new politics or people's politics or the politics of New Leftists. Participatory democracy is believed to be most suitable to increase people's interest in politics. All stakeholders of the Thale Noi have participated actively in the procedure to reduce conflicts in the use of natural resources. All sectors of the community must discuss the measures and arrive at agreements (Pye, 1966).

Trust

Trust refers to belief and acceptance of consequences. Trust can be created by trustworthy persons or work procedures (Hill and O'Hara, 2006). In the past, government officials were considered educated and knowledgeable; therefore, they were trusted and respected in the community. The local government, including heads of villages and heads of sub-districts, was also well respected and trusted. At present, such respect and trust in government officials has diminished because of tourism. There are also conflicts of interest between people of different groups whose interests are different and conflicts between people and officials. Boonprakarn (1999) and Kaewrak (2007) found that the conflicts occurred due to mistrust among these three discordant elements. In all the 15 meetings and discussions the researcher conducted with those who were involved in conflict, the best ways to build trust were addressed. Trust can be established among involved people based on two important factors:

\section{Trust In The Person}

The intermediaries who did not take part in the conflict, such as Nai Amphor (head of the district) and the provincial governor, were selected to convey to people that the conflict would be solved fairly. These two officers can be respected for solving the conflicts; they also command the Territorial Defense Force Volunteers who can provide for the security of the people and the areas (Thamrongthanyawong, 1996).

\section{Trust In The System}

The system is one of the best tools for the reduction of conflict between the stakeholders and officers in the wetlands area of Thale Noi. The provincial level and district level committees concerned with the dissemination of accurate information will impart trust and reduce the misinterpretation of some unclear issues regarding the use of natural resources of the area.

Disciplining Without Punishment

Previously, punishment was employed for violations in the form of verbal warnings, written warnings, formal probationary notices, suspension without payment, demotions, or termination of work. Most of these punishments can cause problems in organizations if they are unfairly practiced. Unjust uses of disciplinary methods 
and punishment can cause damage to an organization (Grote, 2000). Moreover, people did not realize their mistakes or they would not accept that they were wrong. Punishment causes more harm if mistakes are not realized and if people are not self-disciplined, which are important factors for the smooth working of organizations (Gartrell, 1979).

A new approach to punishment - rehabilitation - aims at correction and cure, making the punished change their habits and attitudes and helping them correct their mistakes. This is known as progressive discipline or discipline without punishment. This new approach can be practiced under a mutual agreement between the people involved; it is hoped that the agreement will be accepted and conflicts reduced (Field \& Boesser, 1994).

The conflict in Thale Noi has persisted for a long time and has resulted in lawful punitive measures such as arresting and prosecution in court by the Natural Resource Conservation Office. This system leads to more conflict instead of curing the problem. It is therefore appropriate to use mutual agreements among people of different occupations and area officials (Thamrongthanyawong, 1996). Agreements should be looked over by the members of the involved groups.

Another benefit of mutual agreement is that the people will guard the agreements and punish wrongful deeds themselves using social sanctions, such as excluding a misbehaving person from the community or professional area. This type of social sanction is taken more seriously in the community than lawful punishment and there will be no protests from the community members. In 15 meetings and discussions, the researcher met with the local people and observed that the community could be united by agreements, rules, and regulations that were agreed on by all involved and the responsible officials.

\section{Committees Recognized By The People}

There should be committees to ease conflicts in each area and level according to the hierarchy of administration in local areas, such as villages, districts, or provinces. The president of the committees should be the head of the village, district sheriff, and provincial governor. The reason for this is that people in upcountry Thailand are respectful of these public officials and they have the authority to oversee armed people, such as volunteers, village headman's assistants, and sub district headman's assistants. Research found that these people were respected and trusted by local people and so they should be the leaders in solving the problems and conflicts at each level of local administration.

In practice, the officials in the Ministry of Natural Resources and Environment manage natural resources without supportive laws. The officials do not have armed personnel, so local people do not obey the rules and regulations in natural resource conservation areas. In the meetings and group discussions that the researcher was involved in, the local people in the Thale Noi wetlands agreed to have local administration officers oversee the natural resources conflicts in the area. Another suggestion from the meetings was that women should participate in the discussions.

\section{CONCLUSION}

The growing population caused the overexploitation of the Thale Noi, which then led to the reduction of natural resources. Natural water resources were contaminated with household waste and heavy metals. Natural fires and those set on purpose for clearance of land for rubber and palm oil plantations increased to an area covering 7,221 acres - six times more than in the same period of the previous year. Some of these fires were started just to attract attention and involve higher levels of authority in the problems and conflicts.

The government authorities involved were officials in the Ministry of Natural Resources from different offices that were responsible for the problems and conflicts in the Thale Noi wetland areas. The officials from the Department of Forestry took care of conflicts and unlawful acts in forest areas; those from the Fishery Department were responsible for all the fishery activities and conflicts in non-hunting areas. The punishment for unlawful deeds ranged from arresting and fining to sending cases to court, banishment from the areas, and withdrawal of land ownership. As a result of the above-mentioned problems, conflicts increased. The agriculturists chased away birds that destroyed their cultivation; those involved in tourism activities, including the long-tail boats carrying tourists for 
boat bird tours, wanted a lot of birds in the area; and fishers did not like the long-tail boats because their speed and sound chased away, or even damaged, the fish and their reproductive areas. There were conflicts between each of these groups with different officers guarding other areas and governing different aspects of law violation. There were also conflicts between different sections of governmental units. More importantly, measures such as arrest, expulsion from problem areas, court procedures, and even the abandonment of rights do not work effectively.

The researcher proposed that problems and conflicts should be resolved in an amicable way with the total agreement of all involved parties. He proposed that all groups of people in conflict and all officials responsible for the area should make sure that all agreements and measures are followed and practiced by all sections of the community. These agreements must be based on social principles, which are participatory democracy, trust, discipline without punishment, and committees recognized by the people.

\section{AUTHOR INFORMATION}

Surachet Chiramanee is a Ph.D. candidate in Environmental Management, Prince of Songkla University, Hatyai, Songkhla, Thailand. He is Assoc. Prof in the field of public administration. Tel: +66 869580223 E-mail: Surachet2011@yahoo.com (Corresponding author)

Chidchanok Churngchow is a lecturer at the Faculty of Education Administration, Prince of Songkla University, Pattani Campus, Pattani, Thailand. He is a specialist in social science research methodology. Tel: +66899751766. E-mail: cchidcha@bunga.pn.psu.ac.th

Rotchanatch Darnsawasdi is the Dean of Faculty of Environmental Management, Prince of Songkla University, Hatyai, Thailand. He is a specialist in environmental management and urban planning. Tel: +66 814783197 E-mail: rotchanatch.d@psu.ac.th

\section{REFERENCES}

1. Angkaprechasete, P. (1985). The Changing of Bird Population in the Wildlife Non-Hunting Areas of Talay Noi. Songkhla Thailand: Faculty of Environmental Management, Prince of Songkhla University.

2. Guy P., \& Pierre, J. (2006). Handbook of Public Policy. London, England: Sage Publication.

3. Bill, J., \& Hargrave, R. (1973). Comparative Politics: The Quest for Theory. Columbus, OH: Charles E. Merrill Publishing Company.

4. Boonprakarn, K. (1999). Roles of Public and Private Sectors in Management of Uses a Privileges of Natural Resources in the Wildlife Non-hunting Area of Talay Noi. The Department of Educational Foundations, Faculty of Liberal Arts, Prince of Songkla University.

5. Catt, H. (1999). Democracy in Practice: London, England, and New York, NY: Routledge.

6. Conger, J. (1973). Adolescence and Youth: Psychological Development in a Changing World. New York, NY: Harper \& Row Publishers.

7. $\quad$ Fields, M., \& Boesser, C. (1994). Constructive Guidance and Discipline: Preschool and Primary Education. New York, NY: Macmillan.

8. Gartrell, D. (1997). More thoughts....Punishment or guidance? Young Children, 42(3), 55-61.

9. Grote, D. (2002). Discipline without punishment. Labor Relations Reporter Magazine (November).

10. Hill C., \& O’Hara, E. (2006). A cognitive theory of trust. Washington University Law Review 84 (1717).

11. Kaewrak, S. (2007). The Economical and Social Potentiality in Management of the Community in the Wildlife Non-Hunting Areas of Talay Noi. Prince of Songkla University.

12. Kaewbunsong, S. (2007). A Study of Way of Living of the Thale Noi Community, Kuan Kanun District, Pattalung Province as Found in Local Lullabies (master's thesis, Department of Agriculture Business, Prince of Songkla University).

13. Kantacha, A. (1999). The Research Project of the Contamination of Lead and Chromium from the Waste Water of Dying Sege in Thale Noi. Publish by Department of Chemistry, Thaksin University.

14. Liengponpan, S. (1998). The Research Project of a Survey of Forestry Resources in the Swamp of Thale Noi. Songkhla: Thaksin University.

15. Lindsay, A. D. (1992). The Modern Democratic State. New York, NY: Vantage. 
16. Lomlim, T. 1995). Socio-economical and Political Characteristics and Structure of Power of the Community around the Thale Noi Bay. Southern Srinagarintharawirot University.

17. Maneepong, S., \& Rakkaew Supaporn (1999). A Study of Chemical Characteristics of Substances in the Lake Basins of Thale Noi and Talay Luang. Faculty of Natural Environment, Prince of Songkla University.

18. Mussem, P. (1979). The Psychological Development of the Child. Englewood Cliffs, NJ: Prentice-Hall Inc.

19. Na Chiengmai, N. (2009). The Research Report on The Songkhla Lake Project 1978-1979. Prince of Songkla University and the National Environment Committee.

20. Pateman, C. (1970). Participation and Democratic Theory. Oxford, England: Cambridge University Press.

21. Pye, L. W. (1996). Aspect of Political Development. Boston, MA: Little Brown and Company.

22. Ranthaworn, T. (2002). The Development of Ecological Tourism in the Wildlife Non-hunting Areas in Thale Noi, Pattalung Province. King Mongkut's University of Technology.

23. Rajabhat Songkhla. (2009). The Research Project of Songkhla Thailand: Rajabhat Songkhla University.

24. Sripotchanard, W., Bunthomsin Pornthipa, \& BunyangVoranund. (2006). The Garbage Management of the People in Ban Thale Noi Community in Pattalung Province. Songkhla Thailand: Prince of Songkhla University.

25. Thamrongthanyawong, S. (1996). Political Attitudes of Children and Teenagers in Bangkok (2nd ed.) Bangkok, Thailand: National Institute of Development Administrator. 